\title{
Imagining Global Health with Justice: In Defense of the Right to Health
}

\author{
Eric A. Friedman \\ Georgetown University Law Center, eaf74@law.georgetown.edu \\ Lawrence O. Gostin \\ Georgetown University Law Center, gostin@law.georgetown.edu
}

This paper can be downloaded free of charge from:

https://scholarship.law.georgetown.edu/facpub/1524

http://ssrn.com/abstract=2686296

23 Health Care Analysis 308-329 (2015)

This open-access article is brought to you by the Georgetown Law Library. Posted with permission of the author. Follow this and additional works at: https://scholarship.law.georgetown.edu/facpub

Part of the Health Law and Policy Commons 


\title{
Imagining Global Health with Justice: In Defense of the Right to Health
}

\author{
Eric A. Friedman ${ }^{1} \cdot$ Lawrence O. Gostin $^{1}$
}

Published online: 24 October 2015

(C) Springer Science+Business Media New York 2015

\begin{abstract}
The singular message in Global Health Law is that we must strive to achieve global health with justice-improved population health, with a fairer distribution of benefits of good health. Global health entails ensuring the conditions of good health - public health, universal health coverage, and the social determinants of health-while justice requires closing today's vast domestic and global health inequities. These conditions for good health should be incorporated into public policy, supplemented by specific actions to overcome barriers to equity. A new global health treaty grounded in the right to health and aimed at health equity - a Framework Convention on Global Health (FCGH) — stands out for its possibilities in helping to achieve global health with justice. This far-reaching legal instrument would establish minimum standards for universal health coverage and public health measures, with an accompanying national and international financing framework, require a constant focus on health equity, promote Health in All Policies and global governance for health, and advance the principles of good governance, including accountability. While achieving an FCGH is certainly ambitious, it is a struggle worth the efforts of us all. The treaty's basis in the right to health, which has been agreed to by all governments, has powerful potential to form the foundation of global governance for health. From interpretations of UN treaty bodies to judgments of national courts, the right to health is now sufficiently articulated to serve this role, with the individual's right to health best understood as a function of a social, political, and economic environment aimed at equity. However great the political challenge of securing state agreement to the FCGH, it is possible. States have joined other treaties with significant resource
\end{abstract}

Eric A. Friedman

eaf74@law.georgetown.edu

Lawrence O. Gostin

gostin@law.georgetown.edu

1 O'Neill Institute for National and Global Health Law, Georgetown University Law Center, 600 New Jersey Ave. NW, Washington, DC 20001, USA 
requirements and limitations on their sovereignty without significant reciprocal benefits from other states, while important state interests would benefit from the FCGH. And from integrating the FCGH into the existing human rights system to creative forms of compliance and enforcement and strengthened domestic legal and political accountability mechanisms, the treaty stands to improve right to health compliance. The potential for the FCGH to bring the right to health nearer universal reality calls for us to embark on the journey towards securing this global treaty.

Keywords Right to health - Global health · Justice - Equity - Global health with justice · Framework Convention on Global Health · Public health · Universal health coverage $\cdot$ Social determinants of health

\section{Introduction}

The singular message in Global Health Law (Harvard University Press, 2014) is that absolute reductions in morbidity and premature mortality are not robust indicators of success in the absence of equity. That is, we can achieve high levels of global health but still lag in justice. What would be truly transformative is to achieve both overall population health and fair distribution of the benefits-in other words, Global Health with Justice. What would global health with justice look like? Before answering this pivotal question, consider contrasting narratives, showing how global health can exist in a state of inequality.

The most prominent figures in global health-from Bill Gates and Michael Bloomberg to Margaret Chan and Ban Ki-moon-stress the remarkable progress the world has made in key health indicators, with steadily increasing life expectancies, significant reductions in child and maternal mortality, and millions accessing treatment for HIV/AIDS. Polio eradication is on the horizon, and new gamechanging treatments and vaccines have arrived. The drug pipeline holds great promise. Global health is squarely on the international agenda, with international health assistance tripling since 2000 - though it is now leveling off [32].

But there is an equally powerful narrative prevalent among civil society and right to health advocates. Global Health Law begins with these narratives, stories told in the voice of young people around the world. Namubiru lives in Gaba, Uganda: "I live in a rowdy place, with no clean water, no good toilets or bathrooms. At night, the conditions worsen, with hardly any electricity. The mosquito noise fills up the place. Cockroaches move around me. My mother would help me with medication fees, but she is dying of AIDS. A lot of violence happens here. Life is too hard. After I finish school I will look for a job, to begin a new life and to be able to look after my mother" [16, p. 6].

Time and again, children told us similar stories of suffering, even in rich countries, such as Johnny, who lives on the Blackfeet Tribal Reservation in Montana: "I start my day with a cup of Joe, then corral and break horses, and smoke a bowl of weed. My father snorts coke and gets drunk, taking my birthday money. He beats all the kids. When your family is broken due to drugs and alcohol everyone is hurt. What I mean is what little kids get to eat or not to eat, did they get the shoes or clothes they needed, it depends on whether adults do drugs. I want to shout, 
'When you do meth, hey, don't let your kids be here.' What about the kids?" [16, p. 7].

These two narratives are starkly conflicting, yet both are true. Why? The answer is that while the world makes dramatic improvements in the population's health, the poorest and most vulnerable continue to suffer. It is possible to have global health (overall health improvements) without justice. And it is possible to have greater justice (fairer distribution of the benefits of good health) without global health. We need both, which is why the book's essential message is Global Health with Justice. We now turn to explaining what an ideal state of global health with justice would look like, how to get there, and the critical issue of implementing the right to health raised by the erudite contributions of the eminent scholars John Coggon assembled for this symposium edition of Health Care Analysis.

\section{Envisioning Global Health with Justice}

With our goal of finding pathways to global health with justice-ultimately, that must be the goal of global health law, to develop the legal framework for achieving and sustaining such a transformation-we first need to understand global health.

\section{Global Health}

What would an ideal state of global health look like? This seems like a naïve, selfevident question, but as we shall see, international and national health funding and governance are a long way from achieving anything remotely like a reasonable level of population health, and critical priorities are neglected.

Modern conceptions of global health have evolved from the European states' perceived need for "security" against imported infectious diseases from the Middle East and Asia. Global health was not a matter of high levels of health among all peoples, but rather about the "high politics" of safeguarding richer states from pathogens emanating from the developing world.

The International Sanitary Conventions (ISC) of the late 1800s and early 1900s were developed expressly for this "security" imperative, focusing on diseases such as cholera and plague, concerns of European states. The World Health Organization's (WHO) International Health Regulations (IHR) (2005) and the U.S. Global Health Security Agenda are twenty-first century descendants of the ISC. Yet these focus not on a handful of diseases, but on the full panoply of infectious diseases, known and unknown, and ranging further still to antimicrobial resistance and biological and chemical hazards. Global health security is now more closely aligned with the health of all people, recognizing threats can originate anywhere, and that people everywhere need protection.

Still, the "securitization" of global health is evident even today, focusing mostly on insulating wealthy states from diseases prevalent in low- and middle-income countries. The Ebola epidemic illustrated this point, as rich countries did not pay great attention to Ebola in West Africa until the disease appeared on the doorstep of Spain and the US.

Health security is only one of many dimensions of global health. Global institutions and partnerships span the range of health concerns-AIDS, tuberculosis, 
and malaria, maternal, child, and newborn health, non-communicable diseases, injuries, mental health, and more. Reflecting the broad vision of global health embodied in the landmark Declaration of Alma-Ata of 1978 [8], a new global consensus has been forged around universal health coverage (UHC) [60]. With the Sustainable Development Goals (SDGs) [61], the world is embracing not only UHC, but also clean water, sanitation, and nutritious food for all. Beyond these, global commitments in a host of areas, among them poverty, climate change, education, gender, and employment, hold further promise for better health.

This scope of global health can be captured in three sets of conditions required for good health: public health, health care, and social determinants of health. Public health services have two primary features: they are oriented toward prevention rather than treatment, and they focus mostly on the health of populations rather than on individuals. Public health includes injury and disease surveillance, vector control, hygiene and sanitation, safe nutritious food, and potable water. Population health requires attention to the wide range of conditions that cause death and illness, such as highly processed foods, tobacco, and alcoholic beverages. It also seeks to transform the built environment, including safe vehicles and road design, spaces for recreation, walking, and biking, and environmental controls, protecting against industrial pollutants, transportation, and buildings. While some public health services require modern technology, for the safest cars and cleanest power plants, most need only basic technologies - pipes and refrigeration, for example — and effective regulation, backed by good data, surveillance, and laboratories.

The second condition for global health is UHC, typically understood as health care services provided at the individual level. Health care systems still require a strong infrastructure, such as trained health workers, well-equipped health facilities, well-stocked pharmacies, laboratories, and information systems, along with effective regulation and good governance. These services range from health promotion and clinical prevention through to nursing care, essential medicines, surgery, and medical treatment. They cover rehabilitation and palliative care, span the life cycle, and extend from primary care to emergency and specialized services. Health care and public health are largely synergistic, as they should be part of a unified health system. Still, scholars have expressed concern that, as currently understood, UHC could impede the achievement of population health [50]. UHC must be structured to be sufficiently robust to facilitate population health and individual patient-oriented services.

The third critically important condition for population health is the social determinants of health. Commonly summarized as "the circumstances in which people are born, grow, live, work, and age," [4, p. 2] they include early healthy development, education, income, housing, employment, social inclusion, and nondiscrimination. Their health effects encompass many causal pathways, including creating inherently dangerous environments (e.g., air pollution, violence), biological pathways (e.g., stress, leading to changes in cortisol levels, increasing inflammation), lifelong health effects of stress and nutrition in the womb and early childhood, health literacy, sexual violence and disempowerment, opportunities to exercise health-seeking behaviors (e.g., more nutritious but more expensive food), and influencing health-harming behaviors (e.g., tobacco and alcohol use) [69]. 
Despite some action on broad horizontal health systems and social determinants, most current health financing and governance is constructed vertically by disease, such as global health security, polio eradication, and AIDS, tuberculosis, and malaria programs. There is a movement to flatten out vertical programs, but these silos remain, often crowding out major conditions of ill health, such as noncommunicable diseases, mental health, and injuries.

\section{Adding Justice to Global Health}

Global health with justice is concerned not only with the aggregate level of health, but also with the distribution of health across populations. To what degree can everyone equitably experience and benefit from the conditions required for good health? And to what degree does the happenstance of a person's birth, along with the inequitable distribution of income, power, and other resources, lead to inequalities in these conditions? Global health with justice requires services designed to promote fairness. In a perfect state of justice, whether a person is Japanese or Sierra Leonean, at the top or the bottom of a country's income scale, with more or fewer years of education, man or woman-all will achieve similar health outcomes. In a state of global health with justice, all would experience long, healthy lives. To be sure, no program or service can guarantee health and safety. Yet governments can assure the conditions in which people have a good and equitable chance for health and safety throughout their lives.

The makings of global health with justice are inherent features in all three conditions of good health. Public health services are amenable to being embedded in the human ecology and treated as public goods. Everyone would benefit equitably if healthy conditions were found within the environment: if all homes were built with indoor plumbing, with clean water flowing from taps and toilets that flush; if tobacco control measures were uniformly applied and enforced; if roads were all designed to high safety standards and environmental regulations promulgated and enforced to keep the air that everyone breathes clean. Whether one is rich or poor should not affect a person's ability to live in an environment that is health promoting.

Likewise, UHC aims to develop quality health systems genuinely accessible to all, with financial protection to ensure that cost is not a barrier to care. Health services of uniformly high quality, freely available and accessible to all, would go a long way towards ensuring greater justice.

Central to action on the social determinants of health are measures to "tackle the inequitable distribution of power, money, and resources," [4, p. 2] helping equalize conditions of life that affect health, and would include developing universal systems of social protection that encompass childhood education, child care, and income security for children, the elderly, and people unable to work due to unemployment, sickness, or disability [34, 35]. Social determinants include the dignity and lifesustaining qualities of employment at a decent wage, enough to feed, clothe, and house a family.

Yet justice does not inevitably accompany global health. Even if the conditions for good health were embedded in public policy and the environment, fairer 
distribution of funding and services and measures for overcoming barriers would still be needed. Public health services do not reach all equally. Pipes may be afforded the urban rich but not urban slum dwellers or rural poor, much less the homeless. Poor areas may have no supermarket, and even where nutritious food is available to all, it might not be affordable for all. Cigarette taxes and public smoking bans may apply universally, but stress, marketing ploys, and the lack of cessation programs may still leave poor and marginalized communities most vulnerable to tobacco's harms [14].

Health systems similarly may fail to embrace poorer and other socially disadvantaged populations. Health workers may be concentrated in private health facilities. Poor quality, discrimination, and costs may keep poorer and marginalized populations away from public facilities. Medicines may be accessible only to those who can pay. Most health systems present huge barriers to access, including user fees and few health facilities and health workers in poor or rural areas. Even without cost and supply barriers, there are fundamental impediments to overcome, such as culture, language, and disability.

Meanwhile, those with more money attend better schools and secure jobs that provide not only higher salaries, but also safer workplaces and greater autonomy, leading to reduced stress. Higher socioeconomic status may come with betterresourced social networks, and enable people to dwell in safe housing situated in a clean environment, away from pollution laden industrial zones. Comprehensive social protection systems cover only $27 \%$ of the world's population [35].

In short, absent a concerted effort, the same inequities that afflict the rest of our social systems afflict our public health systems. Health statistics bear this out.

Overall global health is improving. Maternal mortality and child mortality have fallen nearly in half since 1990 [73, 75], and by 2014, deaths from AIDS fell by $42 \%$ off their peak of a decade earlier, as access to treatment expanded greatly [63]. Life expectancy, the most basic measure of global health, has been steadily rising, from 64 in 1990 to 71 in 2013 [74].

Global health with justice, however, remains distant. A person born today in Japan can expect to live 38 years - nearly two generations-longer than a person born in Sierra Leone. The life expectancy difference between high- and low-income countries is 17 years [74]. Progress towards health justice remains stubbornly stagnant. A comparison of life expectancies between high- and low-income countries finds approximately 20 million deaths attributable to health inequitiesmore than one in three-every year since at least 1970, and continuing at least through 2010 [13].

Deep domestic health inequities persist. In at least 15 countries, women in the poorest quintile are at least four times less likely to be attended to by a skilled birth attendant than women in the wealthiest quintile [74]. In the US, American Indians on South Dakota's Pine Ridge Reservation have a life expectancy in the upper 40s [37], about three decades below the national average [74]. The life expectancy of transgender women of color in the US is a numbingly low 35 years [28]. Some inequities are worsening. In 2010, UNICEF analyzed 26 developing countries with decreasing child mortality and found that differences in child mortality rates 
between the richest and poorest households had increased in a majority of the countries-in ten, by at least $10 \%$ [64].

\section{Pathways to Global Health with Justice}

Once we have a sound vision of what an ideal state of global health with justice would look like - the equitable distribution of public health, health care, and social determinants - we need to examine how to get there. What are the financial, governance, policy, and other tools needed to improve the overall health of the population, while reducing glaring health disparities?

\section{Policy Directions}

Achieving global health with justice cannot be the task of health ministries alone, the government alone, or even the task of a single country in isolation. Global health with justice requires Health in All Policies, with all sectors of government analyzing how their policies will affect health equity, and reforming and implementing policies towards that goal [38]. This means industrial policies that strictly regulate emissions of harmful pollutants, including in low-income neighborhoods; drug policies that treat addiction as a public health issue rather than as a crime; urban planning that reduces risk of traffic deaths and maximizes opportunities for walking, biking, and other exercise; and school breakfast and lunch programs to help ensure that children are well-nourished.

Achieving health equity requires an all-of-society effort. Civil society can spur the government to action, hold it accountable, ensure that the priorities and perspectives of marginalized communities reach policymakers, and work directly with communities that lack trust in government. Businesses can obstruct health regulation, skirt workplace safety requirements, and focus on short-term profits-or they can work with government and civil society for affordable, healthy food and the highest standards of workplace health and safety, while designing products and developing therapies to meet the health needs of people in countries with the worst health indicators. Media can shape society's expectations and preferences, promoting healthy or unhealthy foods, glamorizing violence or promoting peace, perpetuating negative stereotypes or introducing us to the realities and humanity of far-flung communities.

Global health with justice is a global endeavor, requiring shared responsibility. International cooperation is vital. This is especially true in sectors that profoundly affect health, such as land use and health security or climate change, with their health impacts most devastatingly felt by countries and communities that are already among the poorest and least healthy.

States bear the primary responsibility for assuring the conditions in which their people can be healthy and safe. Yet, the necessary resources are often beyond what lower-income countries can afford; mutual health assistance is vital [67]. So is global investment in research and development to find solutions to the health needs of people in lower-income countries. Trade and 
intellectual property laws should ensure that medicines are affordable and states have the power to implement regulations to protect their populations' health, from regulating trade in tobacco to ensuring the safety of all food that enters their borders.

These shared responsibilities do not rest with the health sector alone. Global health with justice requires global governance for health-the global analogue of Health in All Policies. Sectors such as trade, intellectual property, agriculture, and migration powerfully affect human health. Not only must all global institutions, laws, norms, and processes that primarily focus on health be directed at improving global health and narrowing health inequities, but so too must those of other global regimes to the extent that they may affect health.

Health governance at all levels-from global through to national and local levels - must operate according to principles of good governance, with governments exercising their responsibility of stewardship on behalf of those whom they serve. This requires governments that are honest, avoiding corruption; transparent, with open and comprehensible decision-making processes; deliberative, with meaningful participation of all stakeholders, including the public, civil society, and marginalized populations, in policy prioritization, formation, implementation, and evaluation; efficient, using resources wisely and effectively, and; accountable, with leaders monitoring and reporting on progress on policies and commitments, taking responsibility for and explaining successes and failures, enabling independent monitoring and evaluation, changing direction as needed, and sanctioning those responsible and providing remedies for failures to meet obligations. These principles extend to all institutional structures, even beyond governments and international organizations.

Good governance requires special attention to those whom societal institutions have left behind or who are at greatest risk without deliberate measures of inclusion-socially disadvantaged, poor, oppressed, and other marginalized and vulnerable populations. Equity, then, goes hand-in-hand with good governance.

These measures of inclusion take several forms. One is instituting policies to overcome barriers to the conditions required for good health, identifying and responding to obstacles for each marginalized population. These include, for example, removing health user fees, training health workers on cultural sensitivity to ensure respectful treatment of indigenous populations, and developing nutrition outreach programs for out-of-school children.

Another requirement for equity is assessing how policies in all sectors and levels of government, including global governance, will affected the marginalized populations. How will energy policies affect health equity, from climate change to localized pollution? What about proposals to expand or contract unemployment insurance, or reform agricultural subsidies? How does detention, whether for prisoners or migrants, affect health, especially mental health, of these inherently marginalized populations? Such assessments ought to be a regular part of policymaking. 


\section{The Right to Health}

The policies and forms of governance that ensure the conditions for global health with justice are broadly, even if incompletely, captured in the human right to health: "the highest attainable standard of physical and mental health" [57, art. 12]. Entitlements under the right to health include clean water, nutritious food, housing, and other underlying determinants of health that extend beyond the health sector, while related human rights obligations address the broader social determinants of health [54].

The principles of good governance are fundamental to all human rights, which include transparency, accountability, and participation among their own core features [30]. "International assistance and co-operation," entailing shared responsibility, is part of treaty obligations for economic, social, and cultural rights [57, art. 2], including health, along with, for example, education, food, housing, and favorable conditions of work. Meanwhile, central to the right to health is the thoroughgoing emphasis on marginalized and vulnerable populations [54].

We will return to the symposium authors' critiques of the right to health. But for now, it is important to understand that the right encompasses a broad range of conditions for good health that reflect our claim that public health, health care, and social determinants are the primary conditions for population health. And while A. M. Viens [66] rightly points out that the right to health is not a precondition of health-out of good will or political calculations, governments may provide high levels of health care even without recognizing this right-it opens pathways to better health through its obligatory nature combined with such principles as universality, participation, and accountability. This may be classified as a "weak functional interdependence," but in practice could mean life or death.

\section{Institutional and Legal Mechanisms}

What institutional and legal mechanisms might advance global health with justice? Numerous proposals respond to different fissures in the road towards that goal. An empowered WHO could help achieve global governance for health, forcefully engaging other international regimes to ensure their consistency with the right to health, while building capacity of ministries beyond health to incorporate health into their policies. It could do far more to guide countries and build national capacity to develop and implement health strategies grounded in the right to health. A global fund for health [46] could help mobilize and allocate funding for universal health coverage and even public health measures. A host of proposals, from the Health Impact Fund [24] and a Medicines Patent Pool [41] to a research and development treaty [5] could direct more research towards the needs of people in poorer countries. And as Attiya Waris and Laila Latif [67] posit in this symposium, enhanced international support to curtail tax evasion and avoidance could be an important source of income for health.

These and other proposals have merit, among many others. Yet all are confined, offering the possibilities of advancing certain dimensions of the demands of global health with justice, but leaving others untouched. Even an empowered WHO would 
neither have the authority and political muscle to raise the necessary resources for global health with justice nor hold governments accountable for failing to meet right to health obligations.

\section{A Framework Convention on Global Health}

That is why we have offered another pathway, one ambitious (many argue overly ambitious and unrealistic) in its political ambitions, with an uphill struggle that we readily acknowledge, but with a comprehensiveness, vision, and human rights grounding that we believe offers major potential for global health with justice: a Framework Convention on Global Health (FCGH) [15, 17, 48]. Achieving the FCGH will require supportive social justice movements, from health to those focused on key social determinants of health, and astutely seeking allies across the varied interests that the FCGH will affect and navigating political processes at WHO and the United Nations [3].

An FCGH need not be an all-or-nothing endeavor or even initially take the form of a binding treaty. A framework convention allows states to agree on core principles and actions, with subsequent protocols that further specify state obligations. And there are more graduated pathways available such as a nonbinding "framework," code of practice, or action plan. It may even be possible to break such a framework up into its component parts-such as standard-setting and financing for the universal conditions of good health, health in all policies, and global governance for health-moving steadily towards the full panoply of conditions for global health with justice.

A non-binding WHO framework would bear similarities to the Global Health Constitution that Jennifer Prah Ruger [49] proposes, though covering additional areas, notably accountability and participation, and more explicitly rooted in the right to health. Such a framework could speak directly to non-state actors, while a treaty would direct their actions through the intermediary of the state.

Ultimately, the FCGH would be a global health treaty that has global health with justice as its fundamental goal and the right to health as its North Star. It would establish minimum standards for universal health coverage and public health measures, with an accompanying national and international financing framework. It would spur progress on social determinants of health through comprehensive public health strategies and Health in All Policies directives. Equity would be a theme throughout the FCGH, including requiring identifying and comprehensively responding to obstacles to the conditions needed for good health that different marginalized populations face, and ensuring that marginalized populations benefit from and are fully involved in all health-related processes, from priority-setting to monitoring, evaluation, and accountability.

Reaching other sectors, the treaty would promote cooperation among states to respect and advance the right to health in other international legal regimes, such as trade, intellectual property, and narcotics. While enforcement and implementation are challenges for all international agreements, the FCGH would establish an effective regime of accountability, focused on empowering civil society to ensure that governments meet their obligations, backed by rigorous monitoring and 
reporting, indicators, detailed guidance, innovative incentives and sanctions, and other tools of international accountability. Protocols could address specific health issues in more detail, such as financing, research and development, and the health workforce.

The power of the FCGH comes in part from its breadth. Unlike other proposals, it would respond to the range of policy directions required for health equity. It could require policy processes that engage all ministries, capacity building (such as sharing lessons learned and training), and modalities to ensure that all policies protect, and where possible promote, health justice, such as through right to health assessments. Measures to improve corporate regulation and possibly create binding right to health-related obligations of corporations through creative measures, such as the Pandemic Influenza Preparedness Framework's use of contracts [71], would enable the FCGH to propel not only governments but also businesses towards advancing the right to health. And central to the FCGH would be measures that empower civil society, such as funding, accountability mechanisms, and assured participation in health-related policymaking.

The FCGH would focus on the principles of good governance, with measures to combat health sector corruption, require transparency in policymaking processes and health officials' assets, ensure participation of the public and marginalized populations, and promote efficiency through improved evidence on effective public health interventions. It would require accountability mechanisms from community through national levels, such as community scorecards, community paralegals [40], inclusive health committees and health assemblies, empowered parliamentary oversight, and right to health justiciability.

Further, building on the right to health as a founding principle of the WHO Constitution, and as Shawn Harmon proposes, WHO leadership on the FCGH could buttress the Organization's ability to resist the "deformity" of an international legal order that can undermine health, while proactively and boldly using its normative powers to advance global health and equity [22].

Yet serious questions have been articulately raised in this symposium-and elsewhere-about detriments of the right to health and the FCGH. Critiques point to widespread disregard of human rights standards and states' unwillingness to accept further binding obligations. To many, it is not wise or even feasible to frame health justice as a "right." We now turn to these challenges.

\section{The Right to Health as a Foundation of Global Health with Justice}

The right to health has transformed over the past several decades, from "little more than a slogan," in the words of the first UN Special Rapporteur on the right to health, Paul Hunt [31, p. 2], to a right enshrined in an expanding majority of national constitutions, with continual development of its standards through national courts and international mechanisms, and new possibilities for accountability. One reason to frame health as a human right is simply because the right to health is one of the most widely adopted treaty obligations in international law. States have 
already agreed to be bound, leaving the vital task of creating far better compliance enhancing mechanisms.

The right to health gained far greater specificity in 2000 with the adoption of General Comment 14 of the UN Committee on Economic, Social and Cultural Rights (CESCR), an "authoritative understanding of the right" [31, p. 2]. Today, more than 100 national constitutions articulate a right to health-including all but one of 33 constitutions adopted from 2000 through 2011 [25], often following powerful civil society advocacy. Indeed, the right to health has inspired and galvanized civil society. From influential national NGOs (e.g., Center for Health, Human Rights and Development in Uganda, SECTION27 in South Africa, Lawyers Collective in India) to global coalitions and movements (e.g., International Federation of Health and Human Rights Organizations, People's Health Movement), the past decade-plus has seen civil society coalesce around this health. Given its ubiquitous adoption and its power at the community level, scholars must think long and hard before jettison it for another framing.

UN treaty bodies have expounded on the right to health $[55,56]$, as have numerous reports of the UN Special Rapporteur on the right to health [45]. The Maastricht Principles on Extraterritorial Obligations of States in the Area of Economic, Social and Cultural Rights seek to consolidate the expanding recognition of extraterritorial responsibilities for economic, social, and cultural rights, including the right to health [39]. The Optional Protocol to the International Covenant on Economic, Social and Cultural Rights came into force in 2013, enabling the CESCR to hear individual cases involving states that ratify it [59].

Courts around the world have applied health-related rights-rights to health, health care, life, and a clean environment. The judiciary has expanded access to lifesaving treatments including in Argentina, Venezuela, India, and South Africa. National courts have extended the right to health well beyond particular treatments. For example, Colombia's Supreme Court ordered an overhaul to the national health insurance scheme so that everyone received the same benefits, rather than a more generous set for those formally employed and for higher earners. Reaching into the realm of public health, courts have required government actions to advance the right to food and protect the right to shelter in India, protect the right to drinking water of an indigenous community in Botswana, and affirm government power to regulate tobacco or demand strong government tobacco regulations in countries including Colombia, Peru, Costa Rica, and India [16, 44, 77].

\section{Individualism and "Rights Talk"}

A primary objection to the right to health, notably by Heather Widdows [68] in this symposium, is that "rights-talk" can be too focused on the individual and even be in tension with the common good and social equity. To be sure, traditional conceptions of "rights" are individually oriented, and there has been good reason for this focus. But we believe that rights, at least socio-economic ones like the right to health, are best understood such that an individual's entitlements is a function of a political, social, and economic environment that is aimed at the commonweal and at equityfor all people are equally endowed with these rights. 
Concern about an individual focus of the right to health has centered on court orders, prominently in Brazil [7] and Colombia [76], where courts have required governments to provide expensive medicines to petitioners, potentially diverting resources that could instead be used for public health or lower-cost health care services that benefit more people, including poorer populations. In our view, courts that apply the right to health without regard to implications of their rulings on equity and resources allocation are misapplying the right, at least as interpreted internationally.

State obligations are limited to what is possible with the maximum available resources, with state actions taking equity into account, including particular concern for marginalized and vulnerable populations. Indeed, General Comment 14 admonishes, "investments should not disproportionately favour expensive curative health services...often accessible only to a small, privileged fraction of the population, rather than primary and preventive health care benefiting a far larger part of the population" [54, para. 19]. The right to health would therefore not require - and indeed, would require that a state does not-allocate its health resources in ways that exacerbate rather than mitigate health inequities.

While we believe that the South African Constitutional Court may be overly deferential to the state regarding its maximum available resources, the Court's basic approach is consistent with this view. Following Article 27 of the South African Constitution, it asks whether the state's decision in relation to the right to health is reasonable, an inquiry that interrogates the equity dimensions of the decision, particularly its effect on the poorest people. As the Court articulated in an early landmark right to housing case, Government of the Republic of South Africa $v$. Grootboom, to be reasonable, the government's housing plan would have to "provide relief for people who have no access to land, no roof over their heads, and who are living in intolerable conditions or crisis situations" [20, para. 99]. Or in the words of Constitutional Court Justice Albie Sachs in a case where the Court upheld a state hospital's decision to allocate dialysis machines based on strict medical criteria, "[i]n all the open and democratic societies based upon dignity, freedom and equality with which I am familiar, the rationing of access to life-prolonging resources is regarded as integral to, rather than incompatible with, a human rights approach to health care" [53, para. 54].

The right to health is not unique among rights in this collective dimension; it is shared across rights. While state action or inaction may violate an individual's rights, the appropriate remedy is frequently structural, with the violation and its underlying causes hardly unique to the particular plaintiff. An indigenous woman discriminated against by a health provider deserves compensation, but a proper remedy may require health worker education and sensitization programs and strengthened accountability mechanisms. A child receiving an unequal education deserves better, which might requiring more equitable ways of financing education across an entire jurisdiction. Workers denied the right to form a union may need to have their organizing effort recognized, but a proper remedy might include more state resources to enforce workers' right to free association. A member of the Rohingya minority in Burma denied a right to vote is surely having her rights 
violated, but a meaningful remedy must ensure the right for the hundreds of thousands of Rohingya similarly denied.

\section{The “Oppositional” Character of Rights}

A closely related criticism of the right to health is Heather Widdows' [68] assertion that human rights are of an "oppositional" nature, the suggestion that rights are a zero-sum endeavor, that if I successfully assert that the state must provide me medicine, then the state will be unable to afford medicine for you. Yet with the right to health inextricably linked to equity, to the extent this oppositional scenario occurs, it will advance health with justice, for example, denying expensive medicine to the few in order to provide essential health services to those previously forced to go without. Furthermore, implementing the right to health includes undertaking public health measures that will have widespread national, and even global, benefits.

This "oppositional" nature is not, moreover, ultimately about rights, but rather about the underlying reality of limited resources. In a world of limited resources, even wealthy countries may be unable to afford all possible health care for everyone. In fact, the rights dimension can create a new conversation, helping overcome the underlying resource limitations. By requiring the maximum available resources to be directed towards health and other rights, human rights obligations may require an increased health budget, making it possible to provide us both the health care we need.

\section{The Problem of Precise Definition}

Scholars also criticize the right to health because it has insufficiently precise definitions of its key features [11]. Certainly, the right is vague and aspirational on its face: what is health, what rights flow from a right to health, and what are the exact services a state must provide? Even the qualifiers in international standards may not help. How to judge whether a state has devoted the maximum of its available resources to health and other rights, or whether it is acting quickly enough to progressively realize the right? What are core obligations, aspects of rights that must be implemented immediately and are defined, though unsatisfactorily, in General Comment 14 [54]?

These are fair questions, with no straightforward answer, hindering accountability. Yet such imprecision is a common feature of law, with broad standards, such as the "reasonable person" in tort or the constitutional doctrines of due process, natural justice, or equal protection. As Paul Hunt remarked, "The right gives rise to difficult concepts that require further elucidation. But the same can be said for many well-established human rights. In my view, the right to health is the victim of a double standard. A higher standard of 'precision' is demanded of the right to health than a number of other human rights and legal concepts" [31, p. 6].

Meanwhile, greater clarity is emerging through the legal literature, UN treaty bodies, and regional and national courts. Scholars have specified criteria for determining whether a state is meeting the maximum available resources requirement of economic, social, and cultural rights [2]. Civil society organizations themselves have adopted metrics to measure whether a state is meeting its resource 
obligations [33]. And we have already drawn attention to general comments and judicial decisions elucidating standards for reviewing state obligations in particular cases.

Further development of right to health law could add greater precision. An FCGH could build on analyses such as those above to do just that. At the same time, some imprecision is inevitable and reasonable, given the complexity of circumstances that could affect states' resource allocation, including the importance of viewing the maximum available resources requirement in the context of expenditures on all rights, not only the right to health, and to allow for evolving understandings of state responsibility.

In other areas, too, greater specificity is possible. The FCGH could require participatory processes to establish a nationally agreed core obligations, while also setting out certain universally applicable core obligations. This would be akin to the Colombian Supreme Court's order in unifying that country's health benefits schemes. Along with requiring a participatory process to establish a universal set of benefits, the Court affirmed that the right to health included core obligations that had to be realized immediately, namely medical services needed to maintain a person's minimum level of subsistence and ordered by a physician, but that were not part of the benefit package and that the patient could not afford [77].

\section{The Realpolitik of State Acquiescence to a Treaty Based on the Right to Health}

Another important critique of the right to health is the political reality that states have little appetite for binding international law in general and rights-based commitments in particular, as Norman Daniels emphasizes in this symposium [6]. Even if the right to health offers a strong substantive basis for global governance for health, is there any chance of establishing such a reality? Would states agree to more effective international accountability mechanisms for the right to health, or more concretely, adopt the FCGH, with greater accountability a chief aim?

Powerful voices have endorsed the idea of an FCGH, including UN SecretaryGeneral Ban Ki-moon [51] and Michel Sidibé, Executive Director of UNAIDS [52]. Yet, from our own FCGH advocacy, we understand colleagues' skepticism [6, 49]. Although sovereignty concerns present powerful obstacles, we see in the global arena evidence that such a right to health grounding of governance is within reach. As we will describe, global implementation of the right to health will serve state interests, states have agreed to other treaties that have fewer reciprocal benefits than the FCGH would have and that impose substantial financial costs, and momentum builds towards greater state accountability. Meanwhile, the FCGH may preserve considerable state sovereignty without undermining its objectives.

States should see the benefits of an FCGH. They have considerable interests in global health security, to protect their own populations and to prevent the economic consequences of infectious disease outbreaks. States committed to measures to improve global health security through the IHR, but as the West African Ebola crisis demonstrated, without strong overall health systems-a concern beyond the scope of the IHR, yet central to the FCGH-everyone is at risk [18]. 
An agreement on health financing whereby wealthier states provide robust mutual assistance while all states devote a minimum level of their own financing, with comprehensive accountability measures, would benefit rich and poor alike. Countries offering assistance would know that their support is being used accountability and is matched by national efforts, while in committing to national expenditures, countries needing support can be confident of receiving it.

Economic benefits of the FCGH should be widespread, as better health contributes to higher productivity and economic growth [36]. Economic growth in lower-income countries will mean larger middle classes, expanding the potential consumer base for domestic businesses and companies abroad, furthering investment and trade.

Investments in health care and public health services would enable lower-income states to meet the health needs of their own populations. Healthier populations with good governance can keep states stable, reduce political violence, and maintain better overall economic vitality. In fragile states, governments would benefit from the potential for newfound trust. These benefits would also flow to neighboring, and indeed all, states, with the potential for mitigating regional and global consequences of instability and disillusionment, such as refugee outflows and extremism.

Beyond these benefits would, most importantly, be participation in a joint venture towards global health with justice, a way to bring an often fractious world together and better realize such commitments as those forged through the Sustainable Development Goals [19].

Could common interests such as these be enough for states to undertake further binding commitments on the right to health? We believe that they could. The FCGH, after all, would not be the first treaty on health, even if it would be the most ambitious. Along with the IHR stands the Framework Convention on Tobacco Control (FCTC) [70]. In contrast to the IHR, with clear international dimensions, FCTC obligations relate primarily to states committing to measures with primarily domestic effect. Yet despite the limited nature of the direct reciprocal benefits of this treaty - and many widely ratified human rights treaties-180 states have ratified it [62].

The precedent for relinquishing significant budget authority is well established. FCTC implementation requires resources including for education, tobacco cessation programs, and enforcing smoking bans. Other treaties, too, require state expenditures, prominently the UN Framework Convention on Climate Change and the Kyoto Protocol, with its greenhouse gas emission targets and the investments in clean energy that these require.

In addition, states have agreed to paying assessed contributions to UN organizations, peacekeeping, and specialized agencies, and to multilateral development banks. These mandatory contributions can add up. In fiscal year 2010, U.S. mandatory contributions to the United Nations, including peacekeeping operations and specialized agencies, totaled $\$ 4$ billion [65]. Meanwhile, members of the European Union commit to transferring a portion of their gross national income, about $0.7 \%$ in 2014, to fund the EU [10].

European Union assessments aside, FCGH health funding obligations would exceed these levels. The magnitude would likely be in the range of current voluntary 
commitments, such as the Abuja Declaration's pledge of African states to allocate at least $15 \%$ of their budgets to the health sector [47], and an appropriate healthrelated portion of the oft-repeated UN commitment of economically advanced countries to spend $0.7 \%$ of their gross national income on Official Development Assistance [58].

The FCGH may be designed to combine funding obligations required for global health with justice with states' desire to maintain a sufficient level of state budgetary sovereignty. For example, an inclusive, participatory process-critically, including civil society at the decision-making table-might be able to override presumptive domestic health spending requirements in the FCGH if this process determined that due to country circumstances, the maximum available resources were more limited. Or wealthier states could justify lower levels of assistance to the health sector if they demonstrated significant contributions to the social determinants of health.

\section{The Enduring Problem of Compliance and Enforcement}

Compliance and enforcement are enduring problems associated with all international law. Ironically, although accountability is a central feature of human rights, international enforcement is limited. This enables extensively ratified human rights treaties to co-exist with prevalent human rights violations. We could be more confident of the effectiveness of the right to health as a basis for global health governance-and of an FCGH-if this governance included more forceful compliance mechanisms than the present human rights regime. We are optimistic that the FCGH would importantly enhance right to health compliance.

First, even without forceful accountability mechanisms, treaties can make a difference. The FCTC, for example, has little by way of compliance mechanisms other than requiring states to periodically report on actions taken to implement the Convention, and on obstacles and measures to overcome them [70]. Yet most states have made significant, though incomplete, progress in implementing the treaty [72]. Human rights legal obligations have been widely incorporated into national constitutions [25] and adjudicated through domestic courts, and have empowered civil society advocacy.

Second, it is worth recognizing that, while inadequate, international human rights enforcement does exist. Though non-binding, the observations and recommendations that human rights treaty bodies issue, along with their reporting requirements and dialogues with states and civil society, are valuable accountability tools [42], and sometimes do lead to state compliance [26].

Potential for greater compliance comes from regional human rights courts, which issue binding judgments. Compliance with orders of the European Court of Human Rights is considered high [23], though varies considerably by state and type of judgment (e.g., compensation or legal reform) [27]; the record on the InterAmerican Court of Human Rights is decidedly mixed [1, 29]; and the African Court on Human and Peoples' Rights has little track record thus far. Regional organizations have also incorporated human rights and democratic rule into their mandates. The Council of Europe can suspend countries for severe human rights violations [21], and the Organization of American States and African Union have 
suspended members following coups that removed democratically elected governments [9, 43].

Thus, integrating the FCGH and its precise right to health requirements with existing human rights machinery should accelerate progress on the right to health.

Third, while states are unlikely to agree to the most forceful tools of peaceful enforcement such as targeted travel bans, asset freezes, and economic sanctions, creative incentives and sanctions are possible. From linking global health leadership positions (e.g., in WHO and the Global Fund to Fight AIDS, Tuberculosis and Malaria) to FCGH compliance to peer review of state compliance, the FCGH could create new pressures on states to implement the right to health. So could clear deadlines, benchmarks, targets, and indicators. And the FCGH could build on existing mechanisms, like UN human rights special rapporteurs, creating more such positions focused on the right to health, enabling far more country engagement than now possible for a single, global rapporteur.

Recent developments suggest some appetite among states-or at least willingness to accept-further accountability measures, as seen in the adoption of the ICESCR Optional Protocol [59]. The UN High-Level Political Forum on Sustainable Development and country-led national review processes offer hope for greater SDG accountability than for the Millennium Development Goals, the SDGs' predecessors, though all SDG follow-up and review processes are voluntary, and an independent review mechanism is absent [61].

And fourth, perhaps the most powerful possibilities for the FCGH to improve compliance come through domestic mechanisms, both legal and political accountability. Drawing on the treaty's precise requirements, domestic courts should be able to more effectively enforce the right to health, including areas that they often avoid, particularly the maximum available resources requirements. The FCGH could establish a right to health capacity fund to strengthen civil society right to health advocates as well as national institutions that have a role in enforcing the right to health (e.g., courts, parliaments, and national human rights commissions). Right to health education and media capacity building could further bolster public pressure for compliance [12]. The FCGH could also require states to take measures to enhance local accountability and participatory mechanisms, such as village health committees, community scorecards, and community paralegals, and to exploit the potential of mobile communications technologies, the Internet, and data collection and analysis for right to health accountability.

\section{Travel Well}

The right to health, with its universal recognition, reach beyond health care alone, and emphasis on equity, is a powerful instrument for global health with justice. Its foundation in the law reflects what we should all recognize about global health with justice-it must not be an optional pursuit of the global community, but rather is a fundamental obligation. The Framework Convention on Global Health holds promise to bring the universal realization of the right to health nearer reality. We agree with our symposium colleagues that achieving the FCGH will be arduous and 
its parameters must be clarified and agreed. But the potential power of a bold convention is too consequential not to pursue it with energy and resolve. When we rise in the morning sometimes it is dispiriting to even contemplate a future of global health with justice. But sometimes wisdom and pursuit are understood through ancient truths. "It is better," said the Buddha, "to travel well than to arrive." We invite readers to travel on a shared adventure for global health with justice [48]. And we may yet arrive.

\section{References}

1. Bailliet, C. M. (2013). Measuring compliance with the Inter-American Court of Human Rights: The ongoing challenge of judicial independence in Latin America. Nordic Journal of Human Rights, 31(4), 477-495.

2. Balakrishnan, R., Elson, D., Heintz, J., \& Lusiani, N. (2011). Maximum available resources and human rights: Analytical report. New Brunswick, NJ: Center for Women's Global Leadership, Rutgers, The State University of New Jersey. http://www.cwgl.rutgers.edu/docman/economic-andsocial-rights-publications/362-maximumavailableresources-pdf/file. Accessed 2 September 2015.

3. Buse, K., Gostin, L. O., \& Friedman, E. A. (2014). Pathways towards a Framework Convention on Global Health: Political mobilization for the human right to health. In M. Freeman, S. Hawkes, \& B. Bennett (Eds.), Law and global health (Current legal issues) (Vol. 16, pp. 37-62). Oxford: Oxford University Press.

4. Commission on the Social Determinants of Health. (2008). Closing the gap in a generation: Health equity through action on the social determinants of health. Geneva: WHO. http://www.who.int/ social_determinants/thecommission/finalreport/en/. Accessed 25 August 2015.

5. Consultative Expert Working Group on Research and Development: Financing and Coordination. (2012). Research and development to meet health needs in developing countries: Strengthening global financing and coordination (pp. 107-126). Geneva: WHO. http://www.who.int/phi/cewg report/en/. Accessed 31 August 2015.

6. Daniels, N. (2015). A progressively realizable right to health and global governance. Health Care Analysis. doi:10.1007/s10728-015-0298-7.

7. de Barcellos, A. P. (2015). Sanitation rights, public law litigation, and inequality: A case study from Brazil. Health and Human Rights, 16(2), 35-46.

8. Declaration of Alma-Ata, International Convention on Primary Health Care, Alma-Ata, USSR, September 6-12, 1978. http://www.who.int/publications/almaata_declaration_en.pdf. Accessed 24 August 2015.

9. Essa, A. (2013). Q\&A: What does the AU suspension mean for Egypt? Al Jazeera, July 6, 2013. http:// www.aljazeera.com/news/africa/2013/07/20137518523285137.html. Accessed 4 September 2015.

10. European Commission. Budget: Financial report 2014, revenue. http://ec.europa.eu/budget/finan cialreport/2014/revenue/index_en.html. Accessed 3 September 2015.

11. Foreman, L., et al. (2014). What could a strengthened right to health bring to the post-2015 health development agenda? Interrogating the role of the minimum core concept in advancing essential global health needs. BMC International Health and Human Rights, 13, 48.

12. Friedman, E. A., \& Gostin, L. O. (2012). Pillars for progress on the right to health: Harnessing the potential of human rights through a Framework Convention on Global Health. Health and Human Rights, 14(1), 4-19.

13. Garay, J., Harris, L., Beam. M., \& Zompi, S. (2013). Global inequity death toll: Targeting global health equity and estimating the burden of inequity. In 141st American Public Health Association Annual Meeting, Boston, MA, USA, Abstr 291133 cited in Chiriboga, D., et al. (2014). Investing in health. Lancet, 383(9921), 949.

14. Goldade, K., Burgess, D., Olayinka, A., Whembolua, G. L. S., \& Okuyemi, K. S. (2012). Applying anthropology to eliminate tobacco-related health disparities. Nicotine and Tobacco Research, 14(6), $631-638$. 
15. Gostin, L. O. (2008). Meeting basic survival needs of the world's least healthy people: Toward a Framework Convention on Global Health. Georgetown Law Journal, 96(2), 331-392.

16. Gostin, L. O. (2014). Global health law. Cambridge, MA: Harvard University Press. (quotations pp. 6-7 condensed and revised).

17. Gostin, L. O., \& Friedman, E. A. (2013). Towards a Framework Convention on Global Health: A transformative agenda for global health justice. Yale Journal of Health Policy, Law, and Ethics, $13(1), 1-75$.

18. Gostin, L. O., \& Friedman, E. A. (2015). A retrospective and prospective analysis of the West African Ebola virus disease epidemic: Robust national health systems at the foundation and an empowered WHO at the apex. Lancet, 385(9980), 1902-1909.

19. Gostin, L. O., et al. (2011). The Joint Action and Learning Initiative: Towards a global agreement on national and global responsibilities for health. PLoS Med. doi:10.1371/journal.pmed.1001031.

20. Government of the Republic of South Africa v Grootboom. (2000). CCT11/00, (Constitutional Court, South Africa), October 4, 2000. http://www.saflii.org/za/cases/ZACC/2000/19.html. Accessed 2 September 2015.

21. Harding, L. (2014). Russia delegation suspended from Council of Europe over Crimea. Guardian, April 10, 2014. http://www.theguardian.com/world/2014/apr/10/russia-suspended-council-europecrimea-ukraine. Accessed 4 September 2015.

22. Harmon, S. H. E. (2015). In search of global health justice: A need to reinvigorate institutions and make international law. Health Care Analysis. doi:10.1007/s10728-015-0296-9.

23. Hart, J. W. (2010). The European human rights system. Law Library Journal, 102(4), 533-559.

24. Health Impact Fund. http://healthimpactfund.org/. Accessed 31 August 2015.

25. Heymann, J., Cassola, A., Raub, A., \& Mishra, L. (2013). Constitutional rights to health, public health and medical care: The status of health protections in 191 countries. Global Public Health, 8(6), 639-653.

26. Heyns, C., \& Viljoen, F. (2002). The impact of the United Nations human rights treaties on the domestic level. The Hague: Kluwer Law International.

27. Hillebrecht, C. (2014). The power of human rights tribunals: Compliance with the European Court of Human Rights and domestic policy change. European Journal of International Relations, 20(4), 1100-1123.

28. Holloway, K. (2015). Five transgender women of color have been murdered in the past five weeks. AlertNet, February 12, 2015. http://www.alternet.org/news-amp-politics/five-transgender-womencolor-have-been-murdered-past-five-weeks. Accessed 26 August 2015.

29. Huneeus, A. (2011). Courts resisting courts: Lessons from the Inter-American Court's struggle to enforce human rights. Cornell International Law Journal, 44(3), 493-533.

30. Hunt, P., \& Backman, G. (2008). Health systems and the right to the highest attainable standard of health. Health and Human Rights, 10(1), 81-92.

31. Hunt, P. (2007). The Millennium Development Goals and the right to the highest attainable standard of health. John D. and Catherine T. MacArthur Foundation international lecture series on population and reproductive health, Abuja, Nigeria, August 17, 2007. https://www.macfound.org/media/article_ pdfs/HUNT_POPULATION.PDF. Accessed 1 September 2015.

32. Institute of Health Metrics and Evaluations. (2015). Financing global health 2014: Shifts in funding as the MDG era closes, Seattle, WA: Institute of Health Metrics and Evaluation. http://www. healthdata.org/policy-report/financing-global-health-2014-shifts-funding-mdg-era-closes. Accessed 24 August 2015.

33. International Budget Partnership. Article 2 and governments' budgets. http://internationalbudget.org/ publications/escrarticle2/. Accessed 2 September 2015.

34. International Labour Organization. (2012). Recommendation concerning national floors of social protection, no. 202. Geneva: ILO. http://www.social-protection.org/gimi/gess/RessourcePDF.action; jsessionid=5e6e0a9dd108f67948cf070859ba1a390ff62b62690f5b86c3ca69f85da6ca34.e3aTbhuLbN mSe34MchaRahaNax50?ressource.ressourceId=31088. Accessed 25 August 2015.

35. International Labour Organization. (2014). World social protection report 2014/15: Building economic recovery, inclusive development and social justice. Geneva: ILO. http://www.ilo.org/global/research/ global-reports/world-social-security-report/2014/WCMS_245201/lang-en/index.htm. Accessed 25 August 2015.

36. Jamison, D. T., et al. (2013). Global health 2035: A world converging within a generation. Lancet, 382(9908), 1898-1955. 
37. Kristof, N. D. (2012). Poverty's poster child. New York Times, May 10, 2012. http://www.nytimes. com/2012/05/10/opinion/kristof-povertys-poster-child.html. Accessed 26 August 2015.

38. Leppo, K., Ollila, E., Peña, S., Wismar, M., \& Cook, S. (eds.). (2013). Health in all policies: Seizing opportunities, implementing policies. Ministry of Social Affairs and Health, Finland. http://www. euro.who.int/_data/assets/pdf_file/0007/188809/Health-in-All-Policies-final.pdf._Accessed 27 August 2015.

39. Maastricht Principles on Extraterritorial Obligations of States in the Area of Economic, Social and Cultural Rights. (2011). Maastricht, The Netherlands, September 28, 2011. http://www.etoco nsortium.org/nc/en/library/maastricht-principles/?tx_drblob_pi $1 \% 5 \mathrm{BdownloadUid} \% 5 \mathrm{D}=23$. Accessed 1 September 2015.

40. Maru, V. (2010). Allies unknown: Social accountability and legal empowerment. Health and Human Rights, 12(1), 83-93.

41. Medicines Patent Pool. http://www.medicinespatentpool.org. Accessed 31 August 2015.

42. Meier, B. M., \& Kim, Y. (2015). Human rights accountability through treaty bodies: Examining human rights treaty monitoring for water and sanitation. Duke Journal of Comparative and International Law, 26(1). http://papers.ssrn.com/sol3/papers.cfm?abstract_id=2596276. Accessed 4 September 2015.

43. Meyer, P. J. (2014). Organization of American States: Background and issues for Congress. Washington, DC: Congressional Research Service. http://fas.org/sgp/crs/row/R42639.pdf. Accessed 4 September 2015.

44. Murli S. Deora vs. Union of India and Ors. (2001). A.I.R. 2002 SC 40 (India). http://www. globalhealthrights.org/wp-content/uploads/2012/11/SC-2001-Murli-S.-Deora-v.-Union-Of-Indiaand-Ors.pdf. Accessed 2 September 2015.

45. Office of the UN High Commissioner for Human Rights. Special rapporteur on the right of everyone to the enjoyment of the highest attainable standard of physical and mental health. http://www.ohchr. org/EN/Issues/Health/Pages/SRRightHealthIndex.aspx. Accessed 1 September 2015.

46. Ooms, G., \& Hammonds, R. (2014). Financing global health through a global fund for health? Chatham House Centre for Global Health Security Working Group Papers. http://www. chathamhouse.org/publications/papers/view/197444. Accessed 31 August 2015.

47. Organisation of African Unity. (2001). Abuja declaration on HIV/AIDS, tuberculosis and other related infectious diseases, Abuja, Nigeria, April 24-27, 2001. http://www.un.org/ga/aids/pdf/abuja_ declaration.pdf. Accessed 3 September 2015.

48. Platform for a Framework Convention on Global Health. http://www.globalhealthtreaty.org. Accessed 1 September 2015.

49. Ruger, J. P. (2013). Governing for the common good. Health Care Analysis. doi:10.1007/s10728015-0294-y.

50. Schmidt, H., Gostin, L. O., \& Emanuel, E. J. (2015). Public health, universal health coverage, and sustainable development goals: Can they coexist? Lancet, 386(9996), 928-930.

51. Secretary-General of the United Nations. (2011). Uniting for universal access: Towards zero new HIV infections, zero discrimination and zero AIDS-related deaths: Report of the Secretary-General. UN Doc A/65/979. New York: United Nations, para 73. http://www.unaids.org/sites/default/files/en/ media/unaids/contentassets/documents/document/2011/A-65-797_English.pdf. Accessed 8 September 2015 .

52. Sidibé, M., \& Buse, K. (2012). A Framework Convention on Global Health: A catalyst for justice. Bulletin of the World Health Organization, 90(12), 870-870A.

53. Soobramoney v Minister of Health (Kwazulu-Natal). (1997). CCT32/97 (Constitutional Court of South Africa), November 27, 1997, http://www.saflii.org/za/cases/ZACC/1997/17.html. Accessed 2 September 2015.

54. UN Committee on Economic, Social and Cultural Rights. (2000). General comment no. 14: The right to the highest attainable standard of health, U.N. Doc. E/C.12/2000/4. http://www1.umn.edu/ humanrts/gencomm/escgencom14.htm. Accessed 28 August 2015.

55. UN Committee on the Elimination of Discrimination against Women. (1999). General recommendation 24, women and health, U.N. Doc. A/54/38. http://www1.umn.edu/humanrts/gencomm/ generl24.htm. Accessed 1 September 2015.

56. UN Committee on the Rights of the Child. (2013). General comment no. 15, the right of the child to the enjoyment of the highest attainable standard of health (art. 24), U.N. Doc. CRC/C/GC/15. http:// www1.umn.edu/humanrts/crc/gencom15.html. Accessed 1 September 2015. 
57. UN General Assembly. (1966). International Covenant on Economic, Social and Cultural Rights (ICESCR). UN G.A. Res. 2200A (XXI). http://www1.umn.edu/humanrts/instree/b2esc.htm. Accessed 27 August 2015.

58. UN General Assembly. (1970). International development strategy for the second United Nations development decade. UN G.A. Res. 2626 (XXV), U.N. Doc. A/RES/25/2626 (1970). http://www.undocuments.net/a25r2626.htm. Accessed 3 September 2015.

59. UN General Assembly. (2008). Optional Protocol to the International Covenant on Economic, Social and Cultural Rights. (2008). UN G.A. Res. 63/117. http://www1.umn.edu/humanrts/instree/optprot08.html. Accessed 1 September 2015.

60. UN General Assembly. (2012). Global health and foreign policy, UN G.A. Res. 67/81, UN Doc. A/RES/67/81, December 12, 2012. http://www.un.org/en/ga/search/view_doc.asp?symbol=A/RES/ 67/81. Accessed 24 August 2015.

61. UN General Assembly. (2015). Transforming our world: The 2030 agenda for sustainable development. https://sustainabledevelopment.un.org/content/documents/7891Transforming\%20Our\%20World. pdf. Accessed 24 August 2015.

62. UN Treaty Collection. Chapter IX: Health. 4. WHO Framework Convention on Tobacco Control. https://treaties.un.org/pages/ViewDetails.aspx?src=TREATY\&mtdsg_no=IX-4\&chapter=9\&lang=en. Accessed 3 September 2015.

63. UNAIDS. (2015). How AIDS changed everything: MDG6: 15 years, 15 lessons of hope from the AIDS response. Geneva: UNAIDS. http://www.unaids.org/en/resources/documents/2015/MDG6_ 15years-15lessonsfromtheAIDSresponse. Accessed 26 August 2015.

64. UNICEF. (2010). Progress for children: Achieving the MDGs with equity, no. 9. New York: UNICEF. http://www.unicef.org/publications/files/Progress_for_Children-No.9_EN_081710.pdf. Accessed 27 August 2015.

65. U.S. Office of Management and Budget. (2011). FY2010 annual report of United States contributions to the United Nations. https://www.whitehouse.gov/sites/default/files/omb/assets/legislative_reports/ us_contributions_to_the_un_06062011.pdf. Accessed 3 September 2015.

66. Viens, A. M. (2015). Interdependence, human rights and global health law. Health Care Analysis. doi:10.1007/s10728-015-0302-2.

67. Waris, A., \& Latif, L. A. (2015). Towards establishing fiscal legitimacy through settled fiscal principles in global health financing. Health Care Analysis. doi:10.1007/s10728-015-0305-z.

68. Widdows, H. (2015). Global health justice and the right to health. Health Care Analysis. doi:10.1007/ s10728-015-0297-8.

69. Woolf, S. H., \& Braverman, P. (2011). Where health disparities begin: The role of social and economic determinants - and why current policies may make matters worse. Health Affairs, 30(10), 1852-1859.

70. World Health Organization Framework Convention on Tobacco Control. (2003). http://apps.who.int/ iris/bitstream/10665/42811/1/9241591013.pdf. Accessed 3 September 2015.

71. World Health Organization. (2011). Pandemic influenza preparedness framework for the sharing of influenza viruses and access to vaccines and other benefits. http://whqlibdoc.who.int/publications/ 2011/9789241503082_eng.pdf. Accessed 1 September 2015.

72. World Health Organization. (2014). 2014 global progression report on implementation of the WHO Framework Convention on Tobacco Control. Geneva: WHO. http://www.who.int/fctc/reporting/ 2014globalprogressreport.pdf. Accessed 3 September 2015.

73. World Health Organization. (2014). Maternal mortality, fact sheet no. 348. http://www.who.int/ mediacentre/factsheets/fs348/en/. Accessed 25 August 2015.

74. World Health Organization. (2015). World health statistics 2015. Geneva: WHO. http://who.int/gho/ publications/world_health_statistics/EN_WHS2015_Part2.pdf?ua=1. Accessed 26 August 2015.

75. World Health Organization. Global health observatory (GHO) data: Under-five mortality. http:// www.who.int/gho/child_health/mortality/mortality_under_five_text/en/. Accessed 25 August 2015.

76. Yamin, A. E. (2014). Promoting equity in health: What role for courts? Health and Human Rights, 16(2), 1-9.

77. Yamin, A. E., \& Parra-Vera, O. (2010). Judicial protection of the right to health in Colombia: From social demands to individual claims to public debates. Hastings International and Comparative Law Review, 33(2), 101-129. 